\title{
BIODIVERSITAS DAN POTENSI JAMUR BASIDOMYCOTA DI KAWASAN KASEPUHAN CISUNGSANG, KABUPATEN LEBAK, BANTEN
}

\author{
BIODIVERSITY AND POTENTIAL OF BASIDIOMYCETES MUSHROOMS IN \\ KASEPUHAN CISUNGSANG REGION, LEBAK, BANTEN PROVINCE
}

\author{
Ahmad Ni'matullah Al Ulya*, Suroso Mukti Leksono, Rida Oktorida Khastini \\ Jurusan Pendidikan Biologi FKIP Universitas Sultan Ageng Tirtayasa
}

*Corresponding author: ulyajr94@gmail.com

Naskah Diterima: 27 Desember 2016; Direvisi: 6 Februari 2017; Disetujui: 15 Februari 2017

\begin{abstract}
Abstrak
Biodiversitas jamur Basidiomycota di kawasan konservasi Taman Nasional Gunung Halimun Salak (TNGHS) yang terletak di Kabupaten Lebak, Provinsi Banten, belum pernah diteliti sebelumnya. Kawasan konservasi tersebut dihuni oleh masyarakat adat dari Kasepuhan Cisungsang, yang selama ini memanfaatkan jamur dalam kehidupan sehari-hari. Oleh karena itu, penelitian ini mengeksplorasi keanekaragaman jamur Basidiomycota dan pemanfaatannya oleh masyarakat adat Kasepuhan Cisungsang. Penelitian dilaksanakan pada bulan Maret-Mei 2016. Sebanyak 34 spesies dari 21 marga, 16 keluarga, dan 5 bangsa dari jamur Basidiomycota berhasil ditemukan di daerah sawah, pekarangan, kebun, talun atau dudukan, dan hutan. Tujuh marga yang ditemukan diketahui dapat dimanfaatkan sebagai sumber makanan, yaitu supa ceuli (Auricularia sp.); supa amis (Marasmiellus sp.); supa beas (Coprinus sp.); supa tiram (Pleurotus sp.); supa jerami (Volvariella sp.); suung tunggal (Termitomyce sp.); dan supa kebo (Boletus sp.). Data ini menunjukkan tingginya biodiversitas jamur Basidiomycota di daerah masyarakat adat wilayah ini dan potensinya sebagai sumber makanan.
\end{abstract}

Kata kunci: Basidiomycota; Kasepuhan Cisungsang; Keanekaragaman hayati

\begin{abstract}
Biodiversity of fungi Basidiomycota in the conservation area of Taman Nasional Gunung Halimun (TNNGHS) Salak in Lebak, Province Banten, has never been studied. This area is resided by indigenous people from Kasepuhan Cisungsang, which uses the fungi in their life. Therefore, this study was aimed at exploring the biodiversity of mushrooms (Basidiomycota) in Kasepuhan Cisungsang. The exploration was conducted from March to May 2016. A total number of 34 species which belong to 21 genera, 16 families, 5 orders were found in the rice field, yard, garden, and forest. About 7 genera are commonly consumed by the community. These include supa ceuli (Auricularia sp.); supa amis (Marasmiellus sp.); supa beas (Coprinus sp.); supa tiram (Pleurotus sp.); supa jerami (Volvariella sp.); suung tunggal (Termitomyce sp.); and supa kebo (Boletus sp.). This study showed a high diversity of mushroom in this area and their potential as a food source.
\end{abstract}

Keywords: Biodiversity; Mushroom; Kasepuhan Cisungsang

Permalink/DOI: http//:dx.doi.org/10.15408/kauniyah.v10i1.4513 


\section{PENDAHULUAN}

Provinsi Banten merupakan daerah dataran tropis yang terletak di ujung barat Pulau Jawa dan dikenal mempunyai kekayaan biodiversitas berupa flora, fauna dan tipe ekosistem yang sangat tinggi dan dilindungi, serta sebagian besar kawasan hutan merupakan kawasan hutan konservasi diantaranya Taman Nasional Ujung Kulon, Taman Nasional Gunung Halimun Salak, Kawasan Taman/Perairan laut, Cagar Alam, Taman Wisata Alam, serta Taman Wisata Perairan (Dinas Kehutanan dan Perkebunan Provinsi Banten, 2012). Ironinya, sebagian besar masyarakat tidak menyadari potensi kekayaan keanekaragaman hayati di Banten, bahkan sebagian besar masyarakat tidak mengenal keberadaan serta potensi keanakeragaman hayati yang dimilikinya.

Salah satu kawasan yang memiliki biodiversitas yang melimpah adalah kawasan konservasi TNGHS yang terletak di Kabupaten Lebak Provinsi Banten. Kawasan konservasi tersebut dihuni oleh masyarakat adat dari Kasepuhan Cisungsang. Warga di daerah ini adalah sekelompok masyarakat adat yang sudah beranak cucu tinggal di kawasan konservasi TNGHS. Kearifan lokal warga dalam mengelola kawasan konservasi TNGHS adalah menyangkut tradisi pemanfaatan dan pengelolaan sumber daya alam secara lestari.

Kearifan lokal dalam pengelolaan sumber daya alam tercermin dalam pengelolaan wilayah yang dilakukan oleh warga kasepuhan. Menurut Leksono et al. (2013), dalam pengelolaan wilayah, masyarakat Kasepuhan Cisungsang memiliki konsep pembagian lanskap secara tradisional. Pembagian lanskap tersebut meliputi wilayah yang disebut dengan lembur, pekarangan, sawah, huma, kebun, talun/dudukuhan, sampalan (ladang pengem-balaan), reuma ngora, reuma kolot, leuweung cadangan, leuweung titipan dan leuweung tutupan (hutan konservasi). Dalam tradisi pemanfaatan keanekaragaman hayati, warga menopang hidupnya dengan mendapatkan sumber makanan dari sekitarnya. Salah satu keanekaragaman hayati yang dimanfaatkan oleh warga sekitar adalah tentang keanekaragaman hayati lokal berupa jamur.
Jamur yang dimanfaatkan oleh warga adalah jamur yang membentuk tubuh buah dan dapat dikonsumsi, yang berasal dari filum Basidiomycota. Hasil observasi awal ditemukan beberapa spesies jamur Basidiomycota yang dimanfaatkan oleh warga sebagai bahan pangan dan obat-obatan, seperti supa ceuli atau disebut juga jamur kuping (Auricularia auricula). Selain itu, ada jamur yang merugikan, seperti cahkokor atau disebut juga Ganoderma sp. yang dapat merusak batang pohon. Oleh karena itu, perlu dilakukan penelitian untuk mengetahui biodiversitas dan pemanfaatan Basidiomycota oleh masyarakat adat Kasepuhan Cisungsang.

\section{MATERIAL DAN METODE}

Penelitian dilakukan di kawasan Kasepuhan Cisungsang yang terletak di Desa Cisungsang, Kecamatan Cibeber, Kabupaten Lebak. Penelitian ini dilaksanakan pada bulan Maret sampai dengan Mei 2016. Pengambilan sampel jamur dilakukan di daerah pekarangan, sawah, kebun, talun, sampalan, dan hutan. Metodologi pengambilan sampel dilakukan dengan metode eksplorasi dan wawancara dengan key person untuk mendapatkan data yang akurat tentang pengetahuan lokal yang berhubungan dengan biodiversitas dan tentang pemanfaatan jamur.

Setelah sampel diperoleh, sampel jamur diidentifikasi dengan menggunakan buku yang berjudul Mushrooms and Other Fungi of The Midcontinental United States karangan Huffman et al. (2008). Pengklasifikasian mengacu kepada literatur digital dan dilanjutkan di Laboratorium Pendidikan Biologi Universitas Sultan Ageng Tirtayasa. Kemudian hasil yang didapat dianalisis secara deskiptif (nonexperiment) yang bertujuan memberi gambaran tentang wilayah studi dan karakteristik yang khas dari objek yang dikaji melalui identifikasi berdasarkan kajian literatur.

\section{HASIL}

Berdasarkan data hasil eksplorasi biodiversitas jamur Basidiomycota di Kasepuhan Cisungsang, diperoleh 34 spesies dari 22 marga (16 keluarga, 5 bangsa) yang ditemukan di sawah, pekarangan, kebun, talun atau dudukan, dan hutan, seperti yang ditunjukkan pada Tabel 1 dan 2 . 
Tabel 1. Data hasil eksplorasi biodiversitas jamur Basidiomycota di Kasepuhan Cisungsang

\begin{tabular}{|c|c|c|c|c|c|}
\hline No. & Nama daerah & Spesies & Marga & Keluarga & Bangsa \\
\hline 1 & Supa ceuli & Auricularia sp. 1 & Auricularia & Auriculariaceae & Auriculariales \\
\hline 2 & & Auricularia sp. 2 & & & \\
\hline 3 & & Auricularia sp. 3 & & & \\
\hline 4 & & Auricularia sp. 4 & & & \\
\hline 5 & Supa amis & Marasmiellussp. 1 & Marasmiellus & Omphalotaceae & Agaricales \\
\hline 6 & & Marasmiellussp. 2 & & & \\
\hline 7 & Supa glenter & Marasmiellussp. 3 & & & \\
\hline 8 & Supa kayu & Gymnopus sp. 1 & Gyтnориs & & \\
\hline 9 & Supa awi & Gymnopus sp. 2 & & & \\
\hline 10 & Supa - & Lentinula sp. & Lentinula & & \\
\hline 11 & Supa beas & Coprinus sp. 1 & Coprinus & Psathyrellaceae & \\
\hline 12 & & Coprinus sp. 2 & & & \\
\hline 13 & Supa bodas & Coprinus sp. 3 & & & \\
\hline 14 & Supa jarum & Coprinus sp. 4 & & & \\
\hline 15 & Supa kayu & Mycena sp. & Mycena & Mycenaceae & \\
\hline 16 & Supa kunir & Gymnopilus sp. & Gymnopilus & Cortinariaceae & \\
\hline 17 & Supa amis & Pleurotus sp. & Pleurotus & Pleurotaceae & \\
\hline 18 & Supa jerami & Volvariella sp. & Volvariella & Pluteaceae & \\
\hline 19 & Suung tunggal & Termitomyces sp. & Termitomyces & Lyophyllaceae & \\
\hline 20 & Supa jarum & Conocybe sp. & Conocybe & Bolbitiaceae & \\
\hline 21 & Supa - & Cyathus sp. & Cyathus & Nidulariaceae & \\
\hline 22 & Supa wereu & Lepiota sp. & Lepiota & Lepiotaceae & \\
\hline 23 & Supa - & Boletus sp. & Boletus & Boletaceae & Boletales \\
\hline 24 & Supa kebo & Boletus sp. & Boletus & Boletaceae & \\
\hline 25 & Supa buled & Sceleroderma sp. & Sceleroderma & Sclerodermataceae & \\
\hline 26 & Supa koneng & Calocera sp. & Calocera & Dacrymycetaceae & Dacrymycetales \\
\hline 27 & Suра kауи & Ganodermata sp. & Ganodermata & Ganodermataceae & Aphylloporales \\
\hline 28 & Supa kayu & Fomitopsis sp. & Fomitopsis & Fomitopsidaceae & \\
\hline 29 & Supa kayи & Cellulariella sp. & Cellulariella & Polyporaceae & \\
\hline 30 & Supa kayu & Trametes sp. 1 & Trametes & & \\
\hline 31 & Supa kayu & Trametes sp. 2 & & & \\
\hline 32 & & Trametes sp. 3 & & & \\
\hline 33 & Supa kayи & Podoscypha sp. 1 & Podoscypha & Meruliaceae & \\
\hline 34 & & Podoscypha sp. 2 & & & \\
\hline
\end{tabular}

Tabel 2. Lokasi ditemukan dan pemanfaatan jamur Basidiomycota di Kasepuhan Cisungsang

\begin{tabular}{|c|c|c|c|c|}
\hline Nama daerah & Marga & Gambar & Lokasi & Manfaat \\
\hline Supa ceuli & Auricularia & & $\begin{array}{ll}\text { - } & \text { Dudukan } \\
\text { - } & \text { Kebun } \\
\text { - Pekarangan } \\
\text { - Sampalan }\end{array}$ & $\begin{array}{l}\text { Dapat } \\
\text { dikonsumi }\end{array}$ \\
\hline $\begin{array}{l}\text { Supa amis/ } \\
\text { supa glenter }\end{array}$ & Marasmiellus & & $\begin{array}{ll}- & \text { Pinggiran hutan } \\
- & \text { Kebun }\end{array}$ & $\begin{array}{l}\text { Dapat } \\
\text { dikonsumi }\end{array}$ \\
\hline
\end{tabular}




\begin{tabular}{|c|c|c|c|c|}
\hline Nama daerah & Marga & Gambar & Lokasi & Manfaat \\
\hline Supa kayu & Gymnopus & & Kebun & \\
\hline Supa & Lentinula & & Hutan pinus & Tidak dapat \\
\hline Supa beas & Coprinus & & Kebun & Dapat \\
\hline Supa bodas & & & Pekarangan & Tidak dapat \\
\hline Supa jarum & & & Pekarangan & Tidak \\
\hline Supa kayu & Mycena & & Sawah & Ragu untuk \\
\hline Supa kunir & Gymnopilus & & Dudukan & Tidak \\
\hline
\end{tabular}




\begin{tabular}{|c|c|c|c|c|}
\hline Nama daerah & Marga & Gambar & Lokasi & Manfaat \\
\hline Supa amis & Pleurotus & & Sawah & $\begin{array}{l}\text { Dapat } \\
\text { dikonsumsi }\end{array}$ \\
\hline Supa jerami & Volvariella & & Sawah & $\begin{array}{l}\text { Biasa } \\
\text { dikonsumsi }\end{array}$ \\
\hline Suung tunggal & $\begin{array}{l}\text { Termitomyce } \\
s\end{array}$ & & Kebun & $\begin{array}{l}\text { Biasa } \\
\text { dikonsumsi }\end{array}$ \\
\hline Supa jarum & Conocybe & & Pekarangan & Tidak dapat \\
\hline Supa - & Cyathus & & Sawah & $\begin{array}{l}\text { Tidak dapat } \\
\text { dikonsumsi }\end{array}$ \\
\hline Supa wereu & Lepiota & & Kebun & $\begin{array}{l}\text { Tidak dapat } \\
\text { dikonsumsi }\end{array}$ \\
\hline Supa kebo & Boletus & & Kebun & $\begin{array}{l}\text { Dapat } \\
\text { dikonsumsi }\end{array}$ \\
\hline
\end{tabular}




\begin{tabular}{|c|c|c|c|c|}
\hline Nama daerah & Marga & Gambar & Lokasi & Manfaat \\
\hline Supa buled & Sceleroderma & & Kebun & $\begin{array}{l}\text { Tidak dapat } \\
\text { dikonsumsi }\end{array}$ \\
\hline Supa koneng & Calocera & & Kebun & $\begin{array}{l}\text { Tidak } \\
\text { dikonsumsi }\end{array}$ \\
\hline Sира kауи & Ganodermata & & Kebun & $\begin{array}{l}\text { Tidak } \\
\text { dikonsumsi }\end{array}$ \\
\hline Sира kауи & Fomitopsis & & Kebun & $\begin{array}{l}\text { Tidak } \\
\text { dikonsumsi }\end{array}$ \\
\hline Sира kауи & Cellulariella & & Kebun & $\begin{array}{l}\text { Tidak } \\
\text { dikonsumsi }\end{array}$ \\
\hline Sира kауи & Trametes & & Kebun & $\begin{array}{l}\text { Tidak } \\
\text { dikonsumsi }\end{array}$ \\
\hline Supa kayu & Podoscypha & & Hutan pinus & $\begin{array}{l}\text { Tidak } \\
\text { dikonsumsi }\end{array}$ \\
\hline
\end{tabular}




\section{PEMBAHASAN}

Hasil penelitian yang telah dilakukan menunjukkan tingginya biodiversitas jamur Basidiomycota di Kasepuhan Cisungsang (Tabel 1). Kelompok yang paling banyak ditemukan adalah dari bangsa Agaricales dengan 10 keluarga, 12 marga, dan 18 spesies. Menurut Tampubolon et al. (2012), bangsa Agaricales merupakan jamur makroskopis yang sering ditemukan dalam beberapa penelitian. Kelompok jamur ini memiliki ciri umum berbentuk tudung seperti payung. Kelompok jamur yang sedikit ditemukan di kawasan ini adalah bangsa Auriculariales (1 keluarga, 1 marga, dan 4 spesies), bangsa Boletales (2 keluarga, 2 marga, dan 3 spesies), dan bangsa Dacrymycetales (1 keluarga, 1 marga, dan 1 spesies). Menurut Suin (2002), faktor lingkungan sangat menentukan penyebaran dan pertumbuhan suatu organisme, yaitu setiap spesies hanya dapat hidup pada kondisi abiotik tertentu yang berada dalam kisaran toleransi yang cocok bagi organisme tersebut.

Kelompok jamur yang sering ditemukan setelah bangsa Agaricales adalah spesiesspesies dari bangsa Aphylloporales (4 keluarga, 5 marga, dan 8 spesies). Wahyudi et al. (2012) menyatakan bahwa di hutan rawa gambut Desa Kuala Dua ditemukan kelompok jamur yang memiliki keanekaragaman cukup tinggi, yang berasal dari ordo Aphylloporales. Oleh karena itu, kelompok Aphylloporales memiliki kemampuan adaptasi yang lebih baik dibandingkan Auriculariales, Dacrymycetales, dan Bolatales. Menurut Hiola (2011), bangsa Aphylloporales banyak tumbuh di pohon-pohon yang tumbang dan sudah lapuk, dengan kondisi optimum suhu yang berkisar $10-15{ }^{\circ} \mathrm{C}$, dan kelembapan sekitar 90\%. Sebagian besar jamur dari bangsa Aphyllophorales yang ditemukan bersifat parasit, yaitu tumbuh pada batang pohon, sehingga dapat menyebabkan kerusakan pada pohon atau pohon menjadi mati (Proborini, 2012).

Faktor kelembapan dan suhu juga mempengaruhi pertumbuhan jamur makroskopis di wilayah ini. Hasil pengukuran kelembapan berkisar 80-91\%, sedangkan suhu berkisar 22-27 ${ }^{\circ} \mathrm{C}$. Menurut Muchroji dan Cahyana (2008), pada umumnya makrofungi dapat tumbuh optimum pada suhu $20-30{ }^{\circ} \mathrm{C}$ dan kelembapan ideal yang dibutuhkan berkisar antara 80-90\%. Namun demikian, pada umumnya suhu, kelembapan, dan intensitas cahaya untuk partumbuhan makrofungi berbeda-beda tergantung dengan spesies makrofungi itu sendiri.

Pemanfaatan jamur Basidiomycota berdasarkan literatur dan keterangan dari beberapa masyarakat Kasepuhan Cisungsang jamur biasanya digunakan sebagai bahan makanan serta obat-obatan tradisional. Hal senada diungkapkan oleh Parjimo \& Andoko (2007), yaitu beberapa spesies jamur telah banyak dimanfaatkan oleh manusia sebagai bahan makanan dan sumber bahan obatobatan tradisional maupun modern. Dari 21 marga yang ditemukan, sebanyak 7 marga jamur dimanfaatkan sebagai sumber makanan oleh warga di wilayah ini dalam kehidupan sehari-hari (Tabel 3). Tujuh marga jamur tersebut adalah supa ceuli, supa amis, supa beas, supa tiram, supa jerami, suung tunggal, dan supa kebo. Sementara itu, jamur yang dimanfaatkan sebagai bahan obat-obatan tradisional belum ditemukan, karena pada saat eksplorasi memiliki beberapa kendala, yaitu cuaca yang tidak mendukung dan akses yang sulit dilalui.

Salah satu contoh jamur Basidiomycota yang dimanfaatkan oleh warga Kasepuhan Cisungsang adalah supa ceuli atau jamur kuping yang sering dimanfaatkan sebagai sumber makanan dikarenakan memiliki rasa yang lezat. Hal ini sesuai dengan kandungan pada jamur kuping sangat tinggi, dengan komposisi: air $89,1 \%$, protein $4,2 \%$, lemak $5,3 \%$ karbohidrat $2,8 \%$, serat $19,8 \%$ dan kalori $351 \mathrm{mg}$ (Muchroji \& Cahyana, 2008; Chang \& Milles, 1989). Sementara itu, supa sinduk atau jamur Lingzhi dimanfaatkan warga sebagai bahan obat. Kandungan pada jamur ini yang bermanfaat untuk obat terdiri dari polisakarida adalah 1,3-D-glukan dan beta-1,6-D-glukan, triterpenoid berupa ganoderic acid, adenosin, protein berupa lingzhi-8, mineral berupa kalium, kalsium, magnesium, sedikit germanium organik, dan senyawa-senyawa lain berupa ergosterol, kumarin, mannitol, vitamin, dan mineral (Direktorat Jenderal Perkebunan Kementerian Pertanian, 2013). 


\section{KESIMPULAN}

Terdapat 34 spesies dari 21 marga, 16 keluarga, dan 5 bangsa jamur Basidiomycota yang ditemukan di sawah, pekarangan, kebun, talun atau dudukan, hutan di wilayah Kasepuhan Cisungsang, Banten. Jamur yang banyak ditemukan adalah anggota dari bangsa Agaricales (10 keluarga, 12 marga, 18 spesies) dan bangsa Aphylloporales (4 keluarga, 5 marga, dan 8 spesies). Jamur yang sedikit ditemukan adalah bangsa Auriculariales (1 keluarga, 1 marga, dan 4 spesies), bangsa Boletales (2 keluarga, 2 marga, dan 3 spesies) dan bangsa Dacrymycetales (1 keluarga, 1 marga, dan 1 spesies). Terdapat 7 marga jamur yang dimanfaatkan sebagai sumber makanan oleh warga di wilayah ini dalam kehidupan seharihari, yaitu Supa ceuli, Supa amis, Supa beas, Supa tiram, Supa jerami, Suung tunggal, dan Supa kebo.

\section{REFERENSI}

Chang, S. T., \& Miles, P. G. (1989). Edible mushroom and their cultivation. Florida: CRC Press.

Dinas Kehutanan dan Perkebunan Provinsi Banten. (2012). Selayang Pandang. Retrieved from http://dishutbun.banten prov.go.id/read/article-detail/strukturorg anisasi/16/Selayang-PandangDinas-Keh utanan-dan-PerkebunanProvinsi-Banten. html

Direktorat Jenderal Perkebunan Kementerian Pertanian. (2013). Jamur ganoderma: peran ganda yang bertentangan. Retrieved from http://ditjenbun. pertanian.go.id/bbpptpsurabaya/tinymcp uk/gambar/file/Ganoderma.pdf

Hiola, F. S. (2011). Keanekaragaman jamur basidiomycota di kawasan Gunung Bawakaraeng (Studi kasus: kawasan sekitar Desa Lembanna Kecamatan Tinggi Moncong Kabupaten Gowa). Bionature, 12(2), 93-100.
Huffman, D. M., Tiffany, L. H., Knaphus, G., \& Healy, R. A. (2008). Mushrooms an other fungi of the midcontinental United States. Iowa City: University of Iowa Press.

Leksono, S. M., Rustaman, N., \& Redjeki, S. (2013). Kemampuan profesional guru dalam memahami dan merancang model pembelajaran konservasi biodiversity di SMA. Cakrawala Pendidikan, 3, 408419.

Muchroji \& Cahyana. (2008). Budidaya jamur kuping. Depok: Penebar Swadaya.

Parjimo \& Andoko, A. (2007). Budidaya jamur. Jakarta: Agromedia Pustaka.

Proborini, M. W. (2012). Eksplorasi dan identifikasi spesies-spesies jamur kelas Basidiomycetes di Kawasan Bukit Jimbranan Bali. Jurnal Biologi, 16(2), 45-47.

Suin, N. M. (2002). Metoda ekologi. Padang: Universitas Andalas.

Tampubolon, M. B., Utomo, B., \& Yunasfi. (2012). Keanekaragaman jamur makroskopis di hutan pendidikan Universitas Sumatera Utara Desa Tongkoh Kabupaten Karo Sumatera. Saintia Biologi, 2, 176-182.

Wahyudi, A. E., Linda, R., \& Khotimah, S. (2012). Inventarisasi jamur makroskopis di hutan rawa gambut Desa Teluk Bakung Kecamatan Sungai Ambawang Kabupaten Kubu Raya. Protobiont, 1(1), 8-11. 